\title{
KAJIAN KONSEP IMAGEABILITY DAN PERMEABILITY DALAM PENGEMBANGAN KAWASAN PUSAT KOTA KOWLOON HONGKONG
}

\author{
Putra Fajar1), Ari Widyati Purwantiasning2) \\ 1)Mahasiswa Prodi Arsitektur Fakultas Teknik Universitas Muhammadiyah Jakarta, Indonesia \\ 2, 3) Dosen Prodi Arsitektur Fakultas Teknik Universitas Muhammadiyah Jakarta, Indonesia \\ Diterima: November 2020; Disetujui: Desember 2020; Dipublikasi: April 2021 \\ *Corresponding author: putrafajaraco@gmail.com
}

\begin{abstract}
Abstrak
Kawasan Kowloon Hongkong merupakan kawasan perkotaan di Hongkong yang terdiri dari Semenanjung Kowloon and New Kowloon, Kawasan ini merupakan pusat kota dari negara hongkong yang mempunyai mobilitas tinggi. Kawasan kowloon memiliki beragam fasilitas seperti perkantoran, komersial, bisnis, fasilitas umum, residensial, konservasi, dan rerkreasi. Arsitektur kawasan sebagian besar memiliki gaya internasional atau modern yang menjadikan infrastruktur nya memiliki kualitas baik dan menjadi daya tarik bagi pengunjungnya. Penelitian ini bertujuan untuk mengkaji konsep imagability dan permeability dalam pengembangan kawasan pusat kota Kowloon dengan menggunakan teori kevin lynch. Imageability merupakan penggambaran kualitas fisik yang dimiliki suatu objek atau kawasan. Permeability merupakan kualitas aksesibilitas dan aktivitas pergerakan manusia pada suatu kawasan. Kawasan Kowloon memiliki imageability dan permeability yang baik yang menjadikan kawasan ini legibility.
\end{abstract}

Kata Kunci : Imageability, Permeability, Kawasan, Pusat kota

\begin{abstract}
The Kowloon Hong Kong area is an urban area in Hong Kong which consists of the Kowloon and New Kowloon Peninsula. This area is the city center of the highly mobile Hong Kong state. The kowloon area has a variety of facilities such as offices, commercial, business, public facilities, residential, conservation and recreation. Most of the regional architecture has an international or modern style that makes the infrastructure of good quality and becomes an attraction for visitors. This study aims to examine the concept of imagability and permeability in the development of the downtown area of Kowloon by using the Kevin Lynch theory. Imageability is a depiction of the physical qualities of an object or area. Permeability is the quality of accessibility and human movement activities in an area. The Kowloon area has good imageability and permeability which makes this area legibility.
\end{abstract}

Keywords: Imageability, Permeability, Regions, City Centers.

How to Cite : Putra F, Ari Widyawati P (2021). Kajian Konsep Imageability dan Permeability dalam Pengembangan Kawasan Pusat Kota Kowloon Hongkong, JAUR Uournal of Architecture and Urbanism Research). 4 (2): 136-148. 


\section{PENDAHULUAN}

Setiap orang yang melakukan wisata berkunjung ke kota-kota di seluruh dunia pasti kurang sempurna apabila tidak menyempatkan untuk jalan-jalan ke pusat kotanya. Pemahaman seseorang tentang suatu kota akan lebih mendalam daripada sekedar kesan visual. Pada suatu kota terdapat banyak arti seperti keindahan, kenangan, pengalaman, harapan, keramaian banyak orang, keragaman bangunan serta drama kehidupan dan kematian, mempengaruhi setiap orang yang mendiami dan memahami suatu kota (Spreiregen, 1996). Menurut YS Rambe Konsep penataan pusat kota pada kota-kota sebenarnya sudah ada sejak jaman prakolonial. Pusat kota disamping sebagai pusat lalu lintas jalan biasanya dilengkapi juga dengan fasilitas tempat ibadah, taman, dan pusat pemerintahan. Jadi pusat kota sebenarnya berpotensi untuk menjadi salah satu identitas bagi kota. (YS, 2018)

$\mathrm{Hal}$ ini penting mengingat beberapa kota sedang dilanda krisis identitas baik dalam bidang arsitektur maupun perencanaan kota. Hal ini mungkin disebabkan karena kurang sadarnya masyarakat akan konsep tata ruang kota dimasa lampau. Kajian ini mencoba untuk dipakai sebagai salah satu pertimbangan untuk menghidupkan kembali pusat kota.

Kualitas fisik yang diberikan oleh suatu kota dapat menimbulkan suatu image yang cukup kuat dari seorang pengamat. Kualitas ini disebut dengan imageability (imagibilitas) atau kemampuan mendatangkan kesan. Imagibilitas mempunyai hubungan yang sangat erat dengan permeability. Permeability (permeabilitas) merupakan kempampuan seseorang mengakses suatu tempat dengan waktu dan jarak yang telatif dekat dan mudah. Perpaduan antara dua elemen tersebut dapat menghadirkan Kawasan kota yang legibility (legibilitas) atau kemudahan untuk dapat dipamahi/dikenali dan dapat diorganisir menjadi satu pola yang koheren (Chapman \& Lynch, 1962).

Dalam penelitian ini penulis ingin mengkaji mengenai "kajian konsep imageability dan permeability dalam pengembanga Kawasan pusat kota".

Adapun tujuan dari penelitian seminar tugas akhir ini adalah Untuk memahami teori imageability dan permeability serta keterkaitan keduanya dan untuk memahami prinsip-prinsip penerapan teori imageability dan teori permeability.

\section{METODE PENELITIAN}

Dalam metode jurnal ini, penulis menggunakan jenis penelitian deskriptif kualitatif dengan dimana setiap aspek-aspek dalam penelitian ini akan dideskripsikan dan diidentifikasikan berdasarkan pada gambaran situasi mengenai fakta-fakta yang ada. Menurut (Sari Pertiwi \& Weganofa, 2015) Artikel ilmiah merupakan sebuah karya tulis yang memaparkan informasi kekinian serta memiliki ciri khas tertentu sesuai pedoman yang ditetapkan.

\section{PEMBAHASAN}

Analisis Teori Permeability Kawasan Kowloon Hongkong Permeability adalah teori yang dikembangkan oleh (Chapman \& Lynch, 1962) membahas tentang aksesibilitas pencapaian suatu ruang, ruang dapat diartikan sebagai proses untuk mencapai suatu ruang baik ruang dari dalam maupun ruang dari luar. Konsep permeability ini di implementasikan pada Kawasan Kowloon Hongkong.

Kawasan Kowloon merupakan Kawasan dengan beragam fungsi yang menjadikannya banyak pergerakan aktivitas. Menurut kevin lynch suatu Kawasan dapat 
dinilai permeabilitynya berdasarkan beberapa aspek yaitu diantaranya :

Blok bangunan yang terjadi di Kawasan Kowloon terbagi menjadi banyak pecahan yang kecil sehingga banyak tercipta blok-blok bangunan. Blok tersebut menjadikan Kawasan Kowloon memiliki kemudahan dalam mencapai suatu tempat karena banyak opsi sirkulasi untuk mencapai suatu tempat. Bentuk blok pada Kawasan Kowloon memiliki bentuk yang tidak beraturan mengikuti alur kondisi geografis dan tepian pantai yang berbatasan langsung dengan laut. Berdasarkan bentuk blok maka dilakukan pengujian untuk mengetahui kemudahan pencapaian pada titik 1 ke titik 2 dan dari titik 2 menuju titik ke 3. Jalur titik 1 berada di bagian selatan dengan nama daerah Shim Sha Tsui menuju permukiman pada jalan Stafford Road dapat diakses kendaraan menggunakan jalur tol Princess Margaret lalu jalur Waterloo Road setelah itu keluar dari tol belok kiri menuju Essex Cres belok kanan ke jalur Cumberland belok kanan menuju Rutland Quadran dan belok kanan lagi menuju Jalan Stafford dan sampailah pada titik 2. Jalur yang ditempuh terasa banyak karena blok terdapaat banyak dan jalan pada permukiman memiliki jalur 1 arah yang membuat pengguna jalur harus mematuhi arah jalan, tetapi meskipun begitu waktu dan jarak yang ditempuh dari titik 1 ke titik 2 mudah dan cepat dengan jalur jalan yang lancer. Selanjutnya pengujian dari titik 2 ke titik 3 dapat diakses melalui jalur seperti pada gambar 1 dengan menggunakan jalur jalan Boundary St, bertemu jalan Prince Edward lalu belok kanan menuju Jalur Wai Yip St. jalan yang ditempuh cukup mudah dan cepat karena jalur memiliki lebar yang besar.

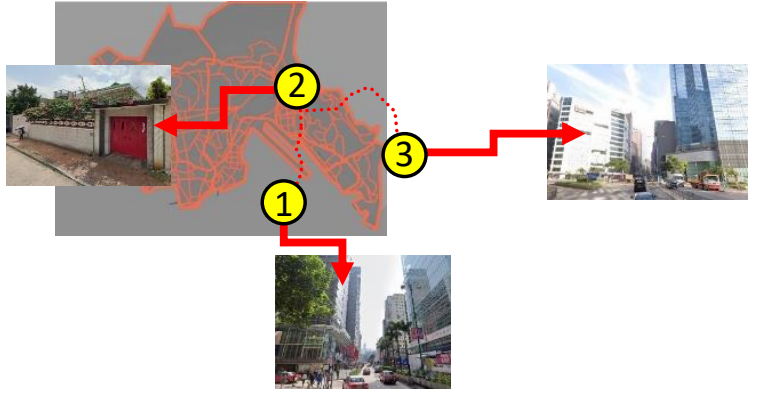

Gambar 1. Akses titik 1 ke 2 ke 3

Sumber: Dokumentasi Pribadi 2020

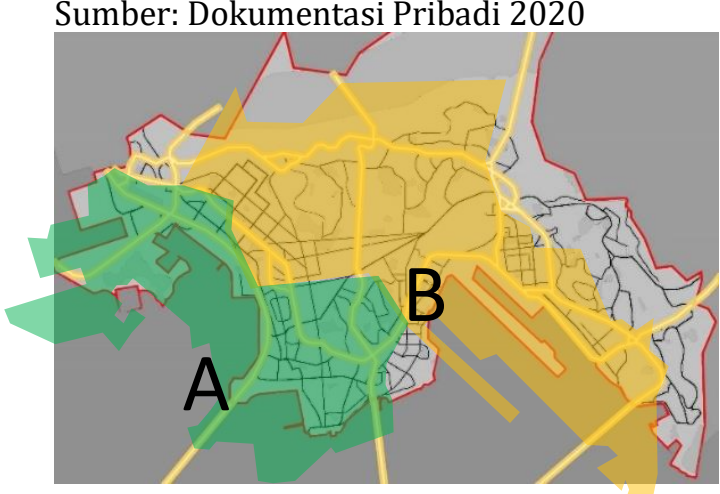

Gambar 2. Blok bangunan kowloon

Sumber: Dokumentasi Pribadi 2020

Pada gambar 2 kawasan yang di diwarnai dengan warna Hijau dan dinamai A memiliki permeability yang tinggi atau memiliki kemudahan akses yang tinggi karena blok tersebut merupakan daerah dengan padat aktivitas dengan mobilitas tinggi blok tersebut terdiri dari perkantoran, hotel, mall, dermaga, taman, tempat, tempat hiburan residensial, perguruan tinggi dan daerah wisatawan. Selain itu daerah ini cenderung memiliki kontur yang rata. Kawasan warna kuning dengan nama B memiliki permeability yang rendah karena pada daerah tersebut merupakan daerah dengan mobilitas dan aktivitas yang rendah, pada blok daerah ini terdiri dari permikiman, pertokoan, dan dermaga. Daerah ini juga memiliki kontur yang tidak rata seperti bukit yang menjadikan blok ini tidak terlalu banyak bangunan. 


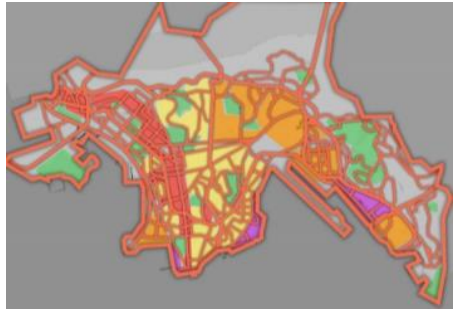

Gambar 3. Permeability Kowloon Berdasarkan Blok Bangunan

Sumber: Dokumentasi Pribadi 2020

Kawasan kowloon memiliki fasad yang berbeda pada setiap bangunannya, kawasan kowloon sebagian besar memiliki gaya arsitektur internasional dan modern dapat dilihat dari gedung-gedungnya dan appartement sebagai tempat tinggal. Namun disamping itu masih banyak bangunan konservasi dengan gaya arsitektur China maupun Eropa yang masih dilestarikan dan dipergunakan sebagai komersial, museum dan rekreasi.

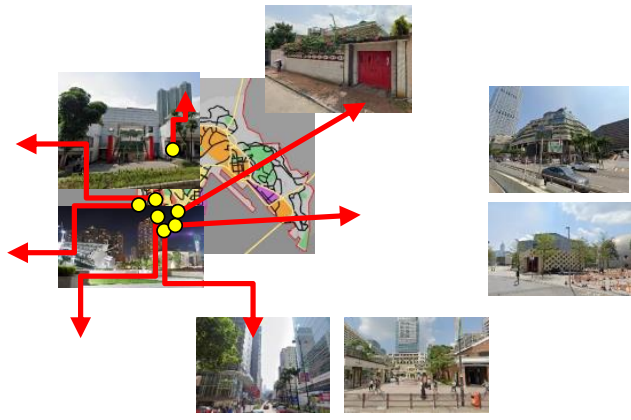

Gambar 4. Blok Kawasan Kowloon

Sumber: Sumber: Google Street View, 2020

Pada gambar 4 menunjukan fasad pada bangunan yang berada di Kawasan Kowloon memiliki keunikan dan ciri khas kawasannya tersendiri pada setiap blok memiliki arsitektur yang kontekstual. kemampuan Permeability pada Kawasan Kowloon memiliki nilai yang baik dengan manajemen kota dan penataan kota yang bai dan mudah untuk mengakses suatu tempat. Menurut suatu lingkungan dengan fungsi yang bermacam- macam dapat dikatakan lebih permeability. (Yavuz, A, dan Kuloğlu, 2014).

Lebar Jalur

Menurut (Silavi T, Farshad H, Christophe C, 2017) apabila jalur sirkulasi dalam sebuah Kawasan itu lebar maka permeabilitas pada Kawasan tersebut juga semakin meningkat.

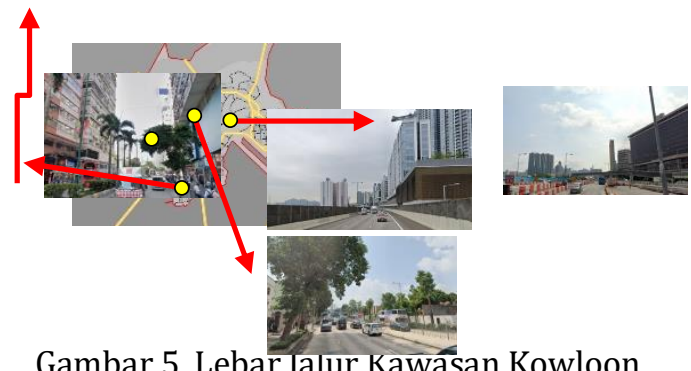

Gambar 5. Lebar Jalur Kawấsan Kowloon Sumber: Google Street View, 2020

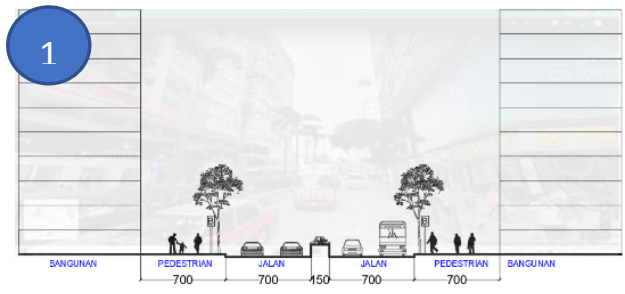

Gambar 6. lebar jalur 1 jalan Nathan road Sumber: Dokumentasi Pribadi 2020

Lebar jalur sirkulasi pada titik 1 jalan merupakan jalur Nathan road memiliki lebar 7 meter 2 lajur dan memiliki 2 jalur. Jalur sirkulasi ini memiliki trotoar yang luas yang dapat memfasilitasi pejalan kaki dalam berhalu lalangm memiliki pepohonan sebagai peneduh dan penyerap karbon dari kendaraan. Pengguna kendaraan dapat melaju dengan baik dengan pengaturan lalu lintas yang baik, jalan ini tidak dibuat dengan terlalu lebar karena jalan dalam kota 
dengan aktivitas yang padat sehingga laju kendaraan tidak terlalu cepat.

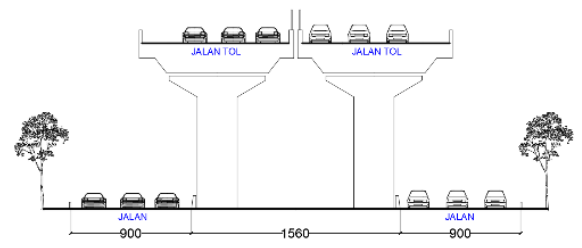

Gambar 7. Jalan 2 West Kowloon hwy \& Lin Cheung Rd

Sumber: Dokumentasi Pribadi 2020

Lebar jalur sirkulasi pada titik 2 merupakan jalur jalan tol west Kowloon highway memiliki lebar sekitar 12 meter 4 lajur, yang digunakan untuk kendaraan hanya 3 lajur dalam 1 jalur karena 1 jalur diperuntukan untuk keadaan darurat seperti melintasnya ambulan, pemadam kebakaran dan kebutuhan darurat lainnya. Sedangkan untuk jalan raya memiliki lebar 9 meter dengan 3 jalur. Jalan ini memiliki aksesibilitas yang cepat karena jarang terjadi kemacetan, disetiap samping jalan ditanam pohon yang rindang.

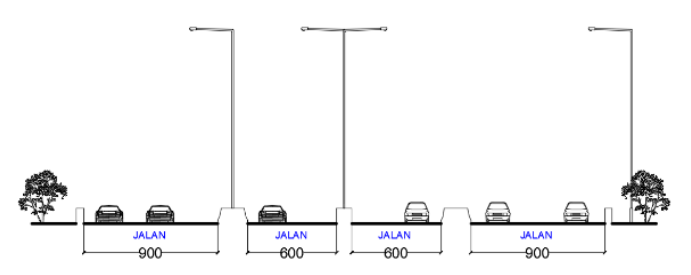

Gambar 8. Jalan 3 Prince Edward Rd Sumber: Dokumentasi Pribadi 2020

Lebar jalur sirkulasi pada titik 3 merupakan Jalan Prince Edward Road memiliki 4 jalur karena jalanan ini merupakan penggabungan dari 4 jalan di Kawasan Kowloon, jalan ini dibuat dengan 4 jalur untuk mencegah terjadinya keramaian berlebih untuk itu dibuat pemisah agar jalanan tetap lancer dan sesuai dengan jalurnya. Untuk bagian tengah jalur memiliki lebar 6 meter, sedangkan pada bagian samping jalur memiliki lebar 9 meter.

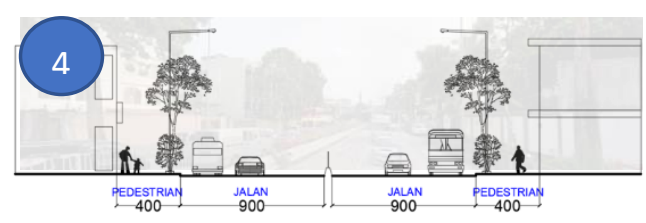

Gambar 9. Jalan 4 Waterloo Rd Sumber: Dokumentasi Pribadi 2020

Lebar jalur sirkulasi pada titik 4 merupakan Jalan Waterloo Road merupakan jalanan yang teletak di pusat kota, jalur ini merupakan jalur tol namun berdekatan dengan bangunan disampingnya. Jalur memiliki lebar 9 meter dengan 3 lajur dan 2 jalur. Trotoar sebagai fasilitas pejalan kaki memiliki lebar 4 meter dengan pelengkapan pepohonan, halte, dan lampu jalan, garis jalan pun terlihan sangat jelas. Jalur ini cukup ramai karena secara letaknya berada di pusat yang merupakan area tingginya mobilitas dan aktivitas para penduduk Kawasan Kowloon.

Penilaian dari lebar jalur pada Kawasan Kowloon memiliki kemampuan permeability yang baik dan mudah dengan beragam aktivitas yang padat pada Kawasan kota metropolitan dan dapat membuat kotanya menjadi teratur.

Hubungan jalur sirkulasi menentukan permeabilitas pada suatu Kawasan karena untuk dapat mengakses suatu tempat ke tempat lain dengan adanya jalur yang saling berhubungan untuk mempermudah dan cepat dalam aksesnya. Kawasan Kowloon merupakan Kawasan pusat kota dari Hongkong sehingga banyak alternatif jalan untuk akses suatu tempat di Kowloon dan dapat merangkul bagian-bagian blok jalan kecil di Kowloon. 


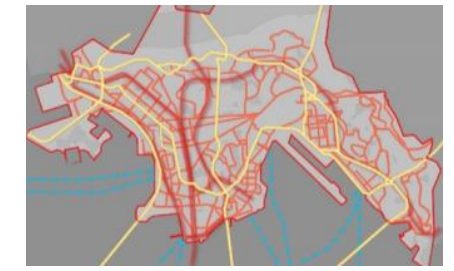

Gambar 10. Moda Transportasi Kowloon Sumber: Dokumentasi Pribadi 2020

Pada Kawasan Kowloon terdapat jalur sirkulasi yang dapat menjadi pilihan untuk bepergian ke suatu tempat diantaranya, Jalan Tol, Jalan Raya, Moda MTR, Moda KMB, dan Moda Kapal.
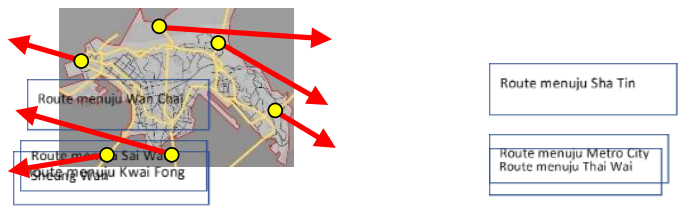

Gambar 11. Hubungan Jalur Jalan Tol

Sumber: Dokumentasi Pribadi 2020

Seperti pada gambar 11 dari jalur jalan luar Kawasan Kowloon dapat mengakses Kawasan Kowloon, terdapat 6 jalan bebas hambatan yang memungkinkan pngunjung dapat dengan mudah memilih alternatif jalur untuk menuju suatu tempat dengan mudah dan cepat.

Moda transportasi pun menjadi indikator permeabilitas pada suatu Kawasan kareana dengan banyaknya moda dan jalur memungkinkan akses ke suatu tempat menjadi lebih mudah dan cepat.
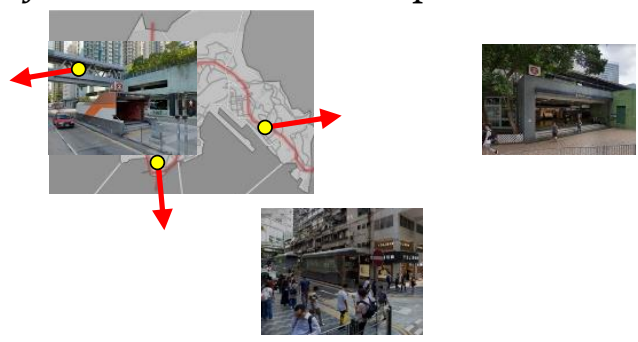

Gambar 12. Moda transportasi MTR Sumber: Google Street View, 2020
Kawasan Kowloon memiliki moda transportasi yang digemari oleh masyarakatnya yaitu MTR atau Mass Transit Railway pada gambar 4.130 menunjukan jalur MTR pada Kawasan Kowloon. Pengguna dapat menaiki MTR ini setiap 5 menit sekali dengan tarif tergantung jauhnya bepergian.

Selain MTR terdapat juga BIS kota untuk mengakses blok-blok kecil Kawasan Kowloon yaitu Kowloon Motor Bus yang dapat dijumpai pada setiap jalan atau pada rambu stop bus. Dengan adanya kendaraan masal ini serta ketersediaan jalur yang memadai permeabilitas Kawasan menjadi tinggi.

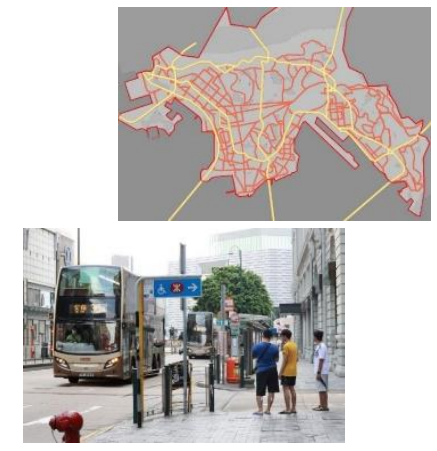

Gambar 13. Moda trsnportasi KMB

Sumber: Dokumentasi Pribadi 2020

Terdapat juga kapal sebagai kendaraan air untuk mengakses suatu pulau pada negara hongkong atau ke negara lain. Kendaraan kapal ini dapat dinikmati oleh setiap kalangan dengan tarif tertentu kapal yang tersedia yaitu kapal ferry, kapal layar.

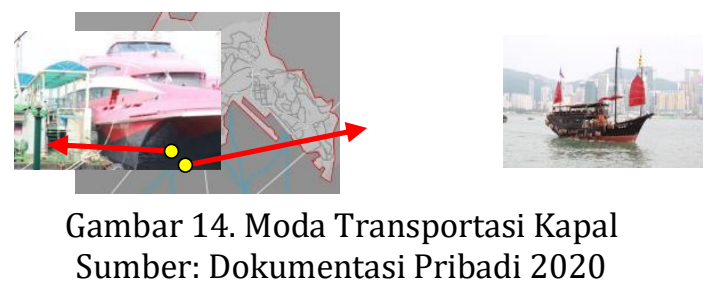


Secara keseluruhan Kawasan kowloon memiliki permeability yang sangat baik, Kawasan ini layak menjadi contoh pengembangan Kawasan. Seseorang yang berkujung pada Kawasan Kowloon dapat dengan mudah mengakses suatu tempat dengan beragam jalur dan moda transit. Kota layak huni adalah kota untuk semua orang, yang berarti kota harus menarik, memiliki dayaguna, aman, semua lapisan masyarakatnya bisa hidup sehat, dan memiliki kesempatan untuk bergerak secara bebas dengan menggunakan moda apa saja. (Hahlweg, 1997).

Materi pembahasan terutama mengupas apakah hasil yang didapat sesuai dengan hipotesis atau tidak, dan kemukakan argumentasinya. Pengutipan rujukan dalam pembahasan jangan terlalu panjang (bila perlu dihindari). Sitasi hasil penelitian atau pendapat orang lain hendaknya disarikan dan dituliskan dalam kalimat sendiri (tidak menggunakan kalimat yang persis sama). Kumpulan penelitian sejenis dapat dirujuk secara berkelompok.

Analisis Teori Imageability Kawasan Kowloon Hongkong, Imageablitity adalah teori yang dicetuskan oleh Kevin lynch yang membahas tentang Gambaran fisik suatu objek kota dapat memimbulkan pengaruh besar dalam image kota yang dapat diterima oleh seseorang. Kualitas fisik yang dihasilkan oleh suatu Kawasan ini di buat dalam 5 elemen diantaranya Path, Edge, District, Node, dan Landmark (Chapman \& Lynch, 1962). Lalu elemen ini dierapkan pada Kawasan penelitian Kowloon Hongkong, Kota baru BSD city Banten, dan Kota baru Parahyangan Bandung.

Kawasan Kowloon Hongkong merupakan Kawasan padat dengan aktivitas dan mempunyai mobilitas tinggi, pusat perdagangan, hotel, rekreasi, tempat bersejarah dan Kawasan wisatawan. Lima elemen berdasarkan teori kevin lynch diimplementasikan sebagai berikut :

Jalur sirkulasi yang saling terhubung mengelilingi Kawasan kota disebut path. Menurut Lynch (1960) path merupakan jalan raya, trotoar, jalur transit, kanal, dan jalur kereta api.

Jalur pejalan kaki terdapat disetiap samping jalan berbatasan langsung dengan bangunan baik bangunan pertokoan, perhotelan, mall, taman. Ukurannya pun bervariasi untuk sirkulasi di daerah ramai memiliki jalur pejalan kaki yang lebar sedangkan sirkulasi pejalan kaki di daerah sepi seperti permukiman memiliki jalur yang kecil.

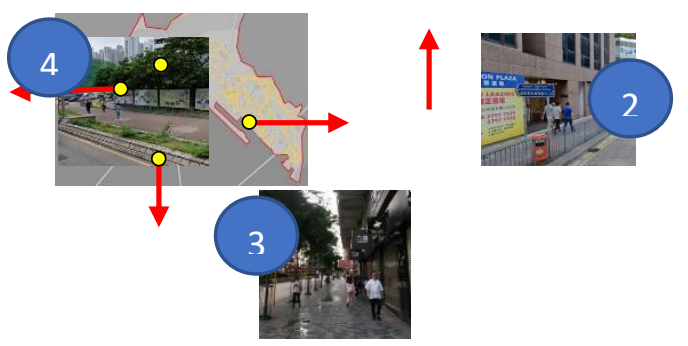

Gambar 15. Path Pejalan Kaki Kawasan Kowloon Sumber: Google Street View, 2020

Pada gambar 15 garis berwarna kuning menunjukan jalan yang memiliki trotoar. Path atau jalur sirkulasi pejalan kaki di Kawasan Kowloon dibuat untuk memfasilitasi pejalan kaki, trotoar dibuat

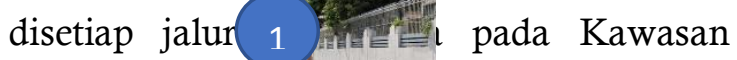
dengan tujuan tempat seperti pertokoan ataupun perkantoran membutuhkan akses yang mana pengunjungnya memerlukan berjalan kaki disetiap samping bangunan tersebut, jalur pejalan kaki atau trotoar ini memiliki ketinggian yang berbeda dengan jalan dengan elevasi sekitar $10 \mathrm{~cm}$ sampai $20 \mathrm{~cm}$ untuk memberikan Batasan yang jelas peruntukannya. Trotoar ini dibangun dengan material paving blok yang dapat menyerap air hujan dan dapat mereduksi 
panas matahari Ketika siang hari, namun sayangnya di beberapa titik belum tersedianya fasilitias guiding blok pada trotoar sehingga desain ini kurang universal user. Kelebihan trotoar di Kawasan Kowloon yaitu pejalan kaki merupakan prioritas utama Ketika ingin menyebrang yang membuat kendaraan harus mengalah jika ada seseorang ingin melintas jalan, sama seperti pada lampu merah yang mana setiap pengguna jalan memiliki hak yang adil untuk saling membutuhkan satu sama lain.

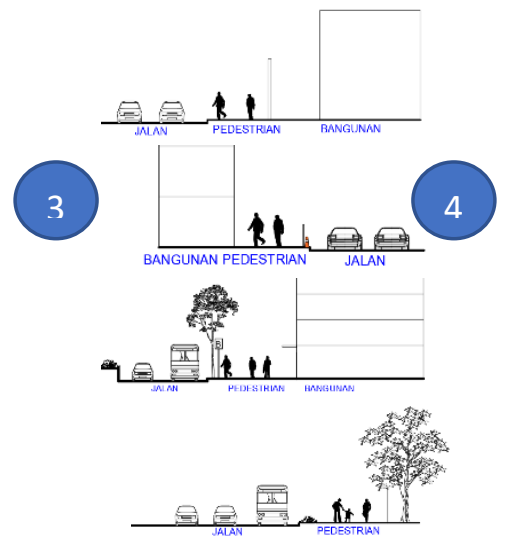

Gambar 16. Potongan Path Pejalan Kaki Kawasan Kowloon

Sumber: Dokumentasi Pribadi 2020
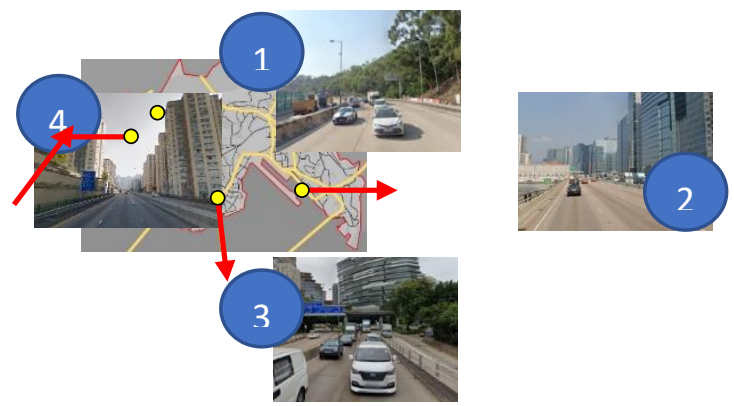

Gambar 17. Path Jalan Bebas Hambatan Tol Sumber: Google Street View, 2020

Pada gambar 17 merupakan jalan bebas hambatan yang berada di Kawasan Kowloon hongkong. jalan tol ini memiliki lebar rata-rata disetiap titik dengan ukuran
9 meter setiap lajurnya serta memiliki 2 jalur. Dari segi volume kendaraan yang menggunakan jalan tol di area pusat kota memiliki volume kendaraan yang cukup tinggi berbeda dengan jalan tol lintas Kawasan jalanan terlihat tidak telalu ramai pengguna.

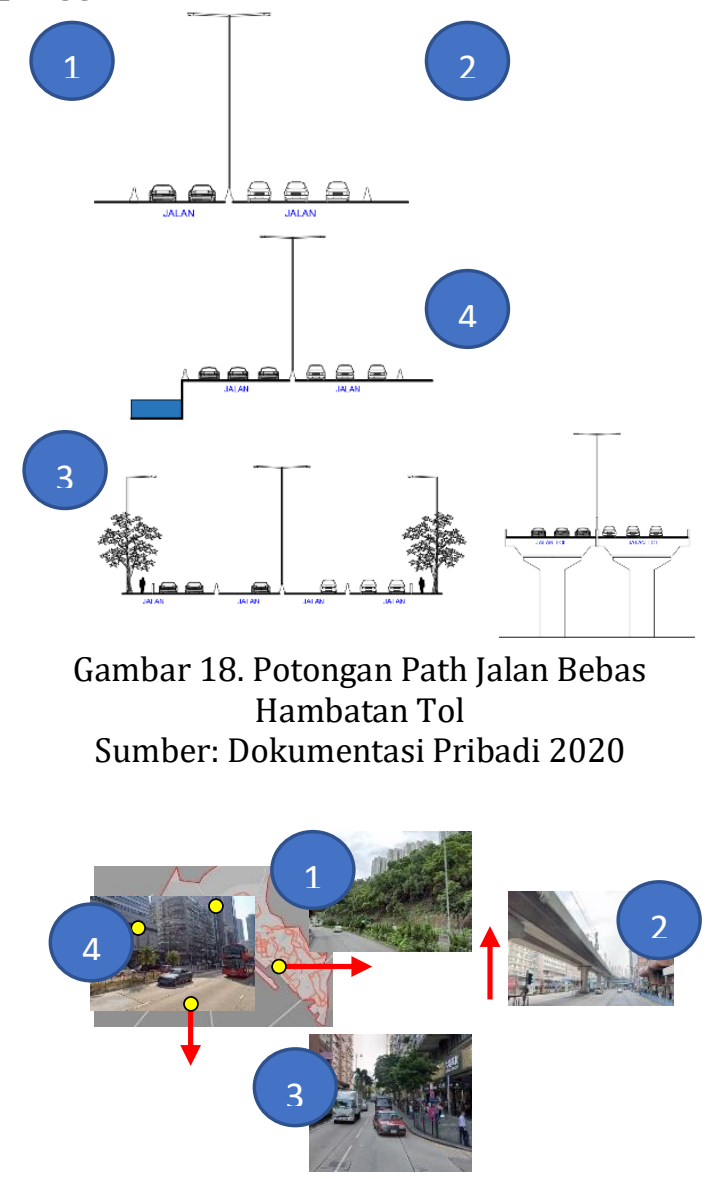

Gambar 19. Path Jalan Raya Kawasan Kowloon Sumber: Dokumentasi Pribadi 2020

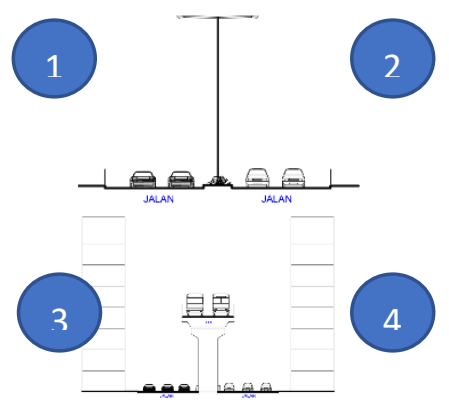




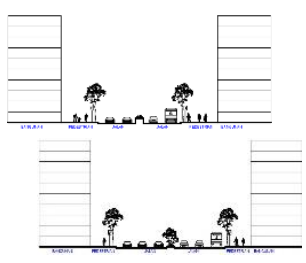

Gambar 20. Potongan Path Jalan Raya Kawasan Kowloon

Sumber: Dokumentasi Pribadi 2020

Dalam kota Kowloon jalur jalan memiliki legibilitas yang jelas, baik itu jalur pejalan kaki, jalan Arteri, Jalan bebas hambatan, jalur rel kereta, dan jalur lainnya. oleh karena itu, (Hartanti \& Trisakti, 2018) mengungkapkan hubungan saling mempengaruhi antara familiaritas, keunikan dan legibility atau keterbacaan. Dalam hal ini, factor keunikan akan memperkuat keterbacaan koridor jalan dan Ketika suatu koridor itu lebih mudah dikenali, maka seseorang akan cenderung memilih atau menyukai untuk melalui jalan tersebut.

Persimpangan jalan atau nodes adalah titik simpul bertemuanya antara jalur atau path. Path yang saling bertemu dan menyilang ini disebut dengan nodes, atau sering disebut dengan pertigaan, perempatan atau simpang 5 .
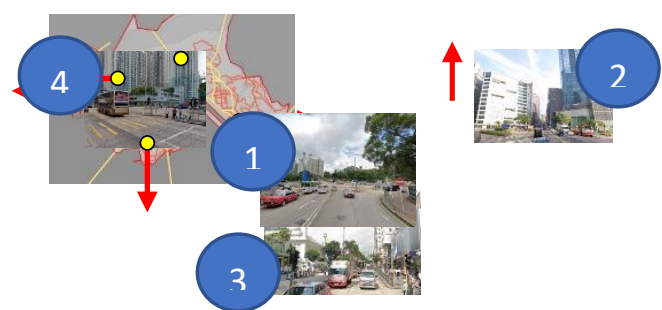

Gambar 21. Nodes Kawasan Kowloon Sumber: Sumber: Google Street View, 2020

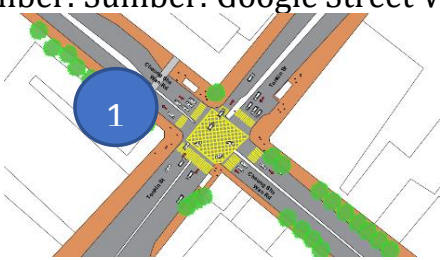

Gambar 22. Node Junction Road Sumber: Dokumentasi Pribadi 2020

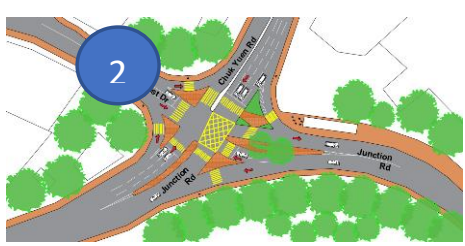

Gambar 23. Moda trsnportasi KMB

Sumber: Dokumentasi Pribadi 2020

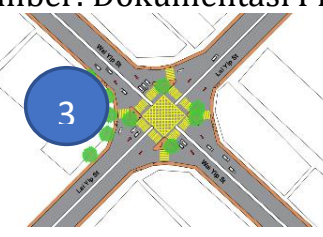

Gambar 24. Node Wai Yip St

Sumber: Dokumentasi Pribadi 2020

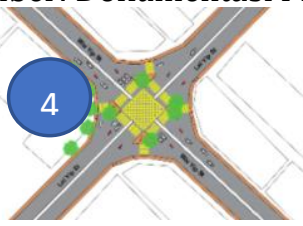

Gambar 25. Node Nathan Road

Sumber: Dokumentasi Pribadi 2020

Landmark merupakan citra kota yang penting untuk menunjukan jati diri suatu Kawasan atau negara. Landmark biasanya dibangun dengan desain mencolok yang dibuat berdasarkan ciri hkas suatu kotanya atau keunikan lokalnya sehingga dapat memberikan makna bagi masyarakat maupun yang melihatnya.

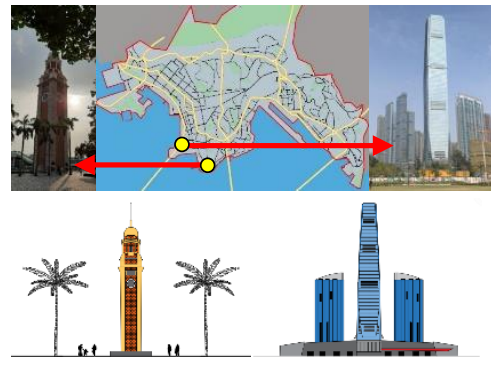

Gambar 26. Landmark Kawasan kowloon Sumber: Dokumentasi Pribadi 2020

Pada Kawasan Kowloon terdapat landmark yang berkesan diantaranya Hongkong Clock Tower dan Gedung ICC (international Commerce Center) keduanya merupakan Menara yang menjulan. Hongkong clock tower memiliki desain yang mencolok dan dapat terlihat Ketika berkunjung ke tepi pantai Victoria harbour, 
pengunjung dapat melihat jam dan berfoto di areal tersebut untuk mengabadikan momen. Gedung ICC merupakan Gedung pencakar langit yang menjadi landmark Kawasan Kowloon Gedung ini memiliki ketinggian 484 meter sehingga seseorang dapat melihatnya dari kejauhan. Pada saat malam hari pada pukul 20.00 sampai dengan pukul 20.10 kota hongkong memiliki pertunjukan seni "Symphony of Lights" pertunjukan ini menampilkan tarian lampu pada Gedung dan lantunan musik khas Budaya Hongkong, pertunjukan gratis dinikmati dan ramai dikunjungi oleh masyarakat maupun turis. Landmark adalah elemen penting dari bentuk kota, karena membantu orang untuk mengorientasikan diri di dalam kota dan membantu orang mengenali suatu daerah (Bappenas, n.d.)

Distrik merupakan sebuah Kawasan yang terletak dalam suatu kota. (Chapman \& Lynch, 1962) mengungkapkan distrik merupakan kawasan kota yang bersifat dua dimensi dimana di dalamnya terdapat bentuk, pola, dan wujud. Kawasan Kowloon befrungsi sebagai Kawasan perbelanjaan, residensial, perkantoran, bisnis, dan rekreasi. Kawasan Kowloon merupakan Kawasan pusat kota metropolitan hongkong, sehingga di masa depan pada masterplan 2030 pembangunan berfokus pada kawasan Kowloon.

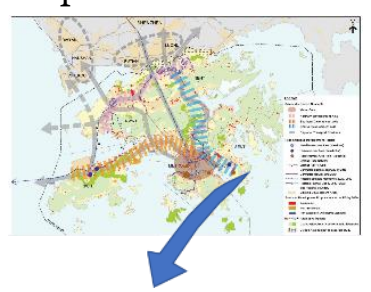

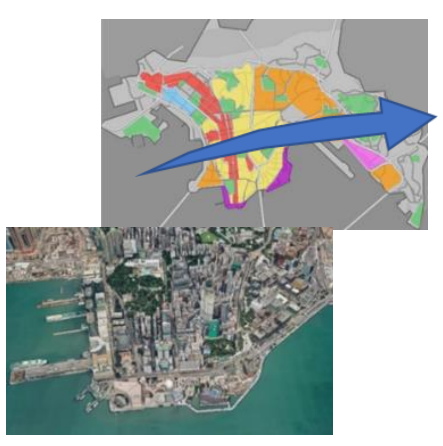

Gambar 27. Distrik Kawasan kowloon Sumber: Hongkong planning and strategy, 2020

Pada gambar 27 menunjukan tentang pusat Kawasan hongkong Kowloon. Kawasan Kowloon memiliki fungsi yang beragam dan padat akan aktivitas penduduknya, Kawasan yang menjadi pusatnya kota hongkong adalah Kawasan Kowloon dan Kawasan pada hongkong island posisinya berada di seberang Kowloon. Untuk membuat rencana dan desain yang sangat baik untuk Distrik Kowloon, perencana kota telah menyediakan bangunan serba guna untuk menampung populasi Kowloon yang dianggap memiliki kepadatan yang relatif tinggi. (Purwantiasning et al., 2019)

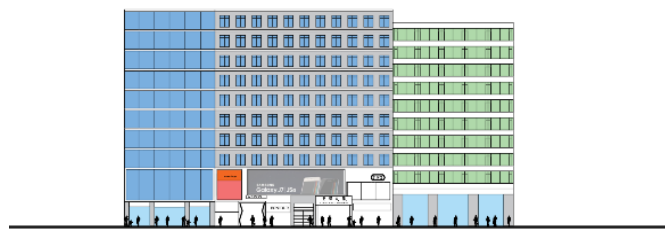

Gambar 1. Blok Distrik Kowloon Sumber: Dokumentasi Pribadi 2020

Blok distrik Kawasan Kowloon memiliki gaya arsitektur yang modern, di areal blok pusat kawasan ini bangunan berupa Gedung mid-rise fungsi lantai dasar merupakan komersial dan lantai atas merupakan hotel. Fasade bangunan merupakan objek utama dalam penilaian kualitas visual, berupa semua bagian 
bangunan yang berhadapan dengan space milik publik, termasuk elemen-elemen bangunan yang membentuk komposisi, proporsi dan dapat menciptakan suatu karakteristik. (Adrian \& Setioko, 2017).

Batas wilayah atau Edge merupakan batas suatu Kawasan. Pada Kawasan Kowloon terdapat Batasan wilayah yang jelas dan biasanya Batasan wilayah yang jelas terdapat pada jalur jalan. (Chapman \& Lynch, 1962) edges merupakan batas-batas antara dua wilayah contohnya seperti danau di Chicago yang membentuk sebuah edges.

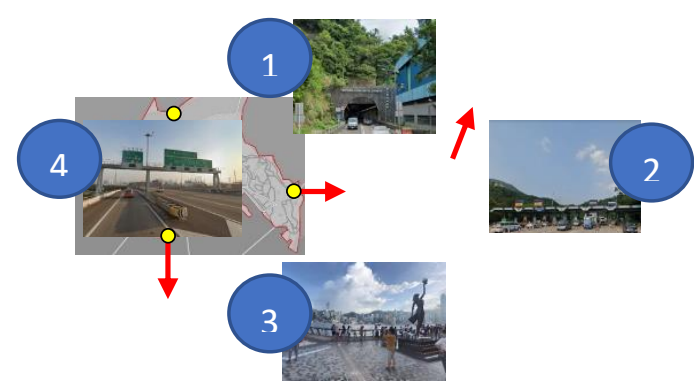

Gambar 28. Edge Kawasan Kowloon Sumber: Sumber: Google Street View, 2020

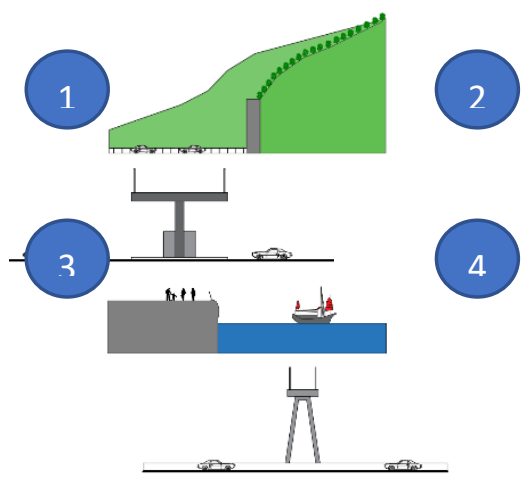

Gambar 29. Potongan Edge Kawasan Kowloon Sumber: Dokumentasi Pribadi 2020

Batasan wilayah bagian barat terdapat pada jalan tol Tsing Kwai Highway terdapat plang rambu lalu lintas yang menunjukan area yang akan ditemui pada Kawasan Kowloon. Batasan wilayah bagian utara terdapat pada terowongan yang menembus bukit perbatasan ini berada diantara Kowloon dan Tai Wai Batasan wilayah ini terlihat jelas dengan menembus terowongan untuk menuju Kawasan Kowloon. Batasan pada bagian timur terdapat pada gerbang tol yang menghubungkan Kawasan Kowloon dengan metro city. Batasan Kawasan pada bagian selatan terdapat pada tepi pantai voctoria harbour batas wilayah berupa pagar yang membentang di tepi pantai.

\section{SIMPULAN}

Imageability merupakan citra yang dapat dirasakan secara visual dan kualitas fisik yang terdapat pada suatu Kawasan atau tempat. Imageability ini berkaitan erat dengan permeability. Permeability merupakan aksesibilitas pencapaian suatu ruang, ruang dapat diartikan sebagai proses untuk mencapai suatu ruang baik ruang dari dalam maupun ruang dari luar kawasan. Imageability dan permeability memberikan kejelasan pada seseorang yang pada suatu Kawasan sehingga memberikan kemudahan dan cepat dalam aktivitas pada suatu Kawasan. Perpaduan antara elemen Imageability dan permeability akan menghadirkan Kawasan kota yang legibility atau dapat diartikan kemudahan untuk dapat dipahami atau dikenali dan terorganisir menjadi suatu pola koheren atau memiliki keterkaitan antara bagian yang satu dengan bagian yang lainnya, sehingga memiliki kesatuan makna yang utuh.

Kawasan Kowloon Hongkong merupakan Kawasan pusat kota dari negara hongkong, di Kawasan ini banyak terdapat bangunan perkantoran, komersial, residensial, bisnis, rekreasi, dan konservasi. Bangunan bersejarah dilakukan konservasi untuk menjaga kelestarianya seperti 
digunakan untuk museum dan perbelanjaan, dan berbagai bangunan lain sebagian besar terbangun bergaya Arsitektur internasional dan high teknologi. Kawasan Kowloon hongkong memiliki kualitas visual yang baik dan dapat memberikan kesan tak terlupakan pada pengunjungnya. Aksesibilitas didukung dengan path dan node dengan baik dan jelas, distrik pada suatu blok terlihat dengan mudah dan jelas, perbatasan wilayah atau edge yang berada di selatan berbatasan dengan laut yang menjadi areal rekreasi menandakan batas yang jelas, distrik pada suatu blok yang tergambargan dengan jelas dan landmark pada Kawasan Kowloon seperti Gedung ICC dan hongkong clock tower memiliki ciri khas yang baik.

\section{DAFTAR PUSTAKA}

Adrian, Moh., and Bambang Setioko. 2017. "FaktorFaktor Yang Mempengaruhi Perubahan Identitas Kota Di Kawasan Kota Tua Muara Tebo Kabupaten Tebo Provinsi Jambi." Jurnal Pembangunan Wilayah \& Kota 13 (4): 459. https://doi.org/10.14710/pwk.v13i4.18265.

Ari Widyati Purwantiasning, Fika Masruroh, Nurhidayah. (2013). ANALISA KAWASAN BOAT QUAY BERDASARKAN. NALARs Volume 12 No 1, 59-72.

Bappenas, Pusbindiklatren. n.d. "Image Kota Baru Tangerang Selatan: Transformasi Metropolitan," 57-61.

Chapman, Edmund H., and Kevin Lynch. 1962. The Image of the City. The Journal of Aesthetics and Art Criticism. Vol. 21. https://doi.org/10.2307/427643.

Google Maps Kowloon Hongkong.

https://www.google.com/maps?q=kowloon+hongko ng+maps\&rlz=1C1NDCM_enID828ID828\&u $\mathrm{m}=1 \& \mathrm{ie}=\mathrm{UTF}$ -

$8 \&$ sa $=$ X\&ved=2ahUKEwjCzv_50vDsAhXXF bcAHfHVCh8Q_AUoAXoECCYQAw

(accesed Mei 5, 2020)
Hongkong 2030 Planning Vision and Strategy. https://www.pland.gov.hk/pland_en/p_study /comp_s/hk2030/eng/finalreport/pdf/E_FR. pdf (accesed Juni 10, 2020)

Hahlweg, D. 1997. "The City as a Family" In Lennard, S. H., S von Ungern Sternberg, H. L. Lennard, Eds. Making Cities Livable. International Making Cities Livable Conferences. California, USA: Gondolier Press.

Hartanti, Nurhikmah B, and Universitas Trisakti. 2018. "KORIDOR JALAN DAN LEGIBILITY KOTA BOGOR The Influence of Street Functional Arrangement to the Imageability of Street Corridors and the Legibility of Bogor City."

Hartanti, N. B. (2018). The Influence of Street Functional Arrangement to the Imageability of. urbanisasi dan pengembangan perkotaan, 70-79.

Muhamad Juliarachman Lazuardia, W. A. (2018). Analisis Citra Kawasan Mangkunegaran berdasarkan Penilaian Stakeholder dengan Konsep Legibility. REGION, 95-114.

Purwantiasning, A. W., \& Ayu Setyoningrum, M. S. (2020). Kajian Permeability dan Imageability Pada Kawasan Konservasi Clarke Quay dan Boat Quay, Singapura. Arsitektur UMJ Press, 1-132.

Purwantiasning, Ari Widyati, Universitas Muhammadiyah Jakarta, Saeful Bahri, and Universitas Muhammadiyah Jakarta. 2019. "Understanding the TOD Concept of Historical Areas Through Precedent Studies," no. July.

Rambe Yunita Syafitri. 2018. Pengembangan Kawasan pada Kecamatan Medan Labuha sebagai Kawasan Suaka Alam dan Cagar Budaya. JAUR, Vol 1 No. 2, 10-22.

Sari Pertiwi, Widya Hanum, and Riza Weganofa. 2015. "Pemahaman Mahasiswa Atas Metode Penelitian Kualitatif: Sebuah Refleksi Artikel Hasil Penelitian." LiNGUA: Jurnal Ilmu Bahasa Dan Sastra $10 \quad$ (1): 18 https://doi.org/10.18860/ling.v10i1.3029.

Sitti Rahma Sy. Wahab, D. M. (2018). KAJIAN ELEMEN PEMBENTUK CITRA KOTA BITUNG. Jurnal Spasial, 238-248.

Silavi T, Farshad H, Christophe C, dan Farshad N. 2017. "The Legibility and Permeability of 
Putra F, Ari Widyawati P, Kajian Konsep Imageability dan Permeability dalam Pengembangan Kawasan

Cities: Examining the Role of Spatial Data and Metrics.," 1-20.

Wafirul Aqli1, Lily Mauliani, Anisa. (2019). PERMEABILITAS KAWASAN JALAN MH. THAMRIN TERHADAP AKSES PEJALAN. NALARs Jurnal Arsitektur Volume 18 Nomor 1, 75-84.

WEISHAGUNA, ERNADY SAODIH. (2007). MORFOLOGI SEBAGAI PENDEKATAN MEMAHAMI KOTA. Jurnal PWK Unisba, 56-67.

Wulanningrum, S. D. (2014). Elemen-elemen Pembentuk Kota yang Berpengaruh terhadap citra kota (studi kasus: kota lama semarang). Jurnal Pembangunan Wilayah dan Kota, 198204.

Yavuz, A, dan Kuloğlu, N. 2014. "Permeability as an Indicator of Environmental Quality: Physical, Function, Perceptual Components of The Environment." World Journal of Environmental Research, 29-40.

Zahnd, Markus. 1999. PERANCANGAN KOTA SECARA TERPADU. Yogyakarta 